\title{
Phosphorylation of basic amino acid residues in proteins: important but easily missed
}

\author{
Joanna Cieśla ${ }^{1,2, \otimes}$, Tomasz Frączyk ${ }^{1, \star}$ and Wojciech Rode ${ }^{1}$ \\ ${ }^{1}$ Nencki Institute of Experimental Biology, Polish Academy of Sciences, Warszawa, Poland; 2Faculty of Chemistry, Warsaw Technical University, \\ Warszawa, Poland
}

\begin{abstract}
Reversible phosphorylation is the most widespread posttranslational protein modification, playing regulatory role in almost every aspect of cell life. The majority of protein phosphorylation research has been focused on serine, threonine and tyrosine that form acid-stable phosphomonoesters. However, protein histidine, arginine and lysine residues also may undergo phosphorylation to yield acid-labile phosphoramidates, most often remaining undetected in conventional studies of protein phosphorylation. It has become increasingly evident that acid-labile protein phosphorylations play important roles in signal transduction and other regulatory processes. Beside acting as high-energy intermediates in the transfer of the phosphoryl group from donor to acceptor molecules, phosphohistidines have been found so far in histone $\mathrm{H} 4$, heterotrimeric G proteins, ion channel KCa3.1, annexin 1, P-selectin and myelin basic protein, as well as in recombinant thymidylate synthase expressed in bacterial cells. Phosphoarginines occur in histone $\mathrm{H3}$, myelin basic protein and capsidic protein VP12 of granulosis virus, whereas phospholysine in histone $\mathrm{H} 1$. This overview of the current knowledge on phosphorylation of protein basic amino-acid residues takes into consideration its proved or possible roles in cell functioning. Specific requirements of studies on acid-labile protein phosphorylation are also indicated.
\end{abstract}

Keywords: basic amino acids, posttranslational modification, phosphorylation, acid-labile, base-stable, phosphoramidate

Received: 05 March, 2011; revised: 05 April, 2011; accepted: 30 April, 2011; available on-line: 27 May, 2011

\section{INTRODUCTION}

The great diversity of the proteome, in comparison to the relatively small number of genes, is achieved mainly by posttranslational protein modifications of which over 100 are known, with phosphorylation being the most widespread. It is estimated that up to $30 \%$ of proteins in a mammalian cell are phosphorylated at any time (Cohen, 2000). Reversible protein phosphorylation affects every basic cellular process, including metabolism, growth, division, differentiation, motility, organelle trafficking, membrane transport, muscle contraction, immunity, learning and memory (Manning et al., 2002; 2002a). Abnormal phosphorylation events are implicated in many disease states. Phosphorylation and dephosphorylation are catalyzed by protein kinases and phosphatases, respectively, responding to different stimuli and thus the two reactions being separately controlled events. Consid- ering the chemistry of the bond between phosphate and an amino acid side chain, phosphoramino acids include phosphomonoesters (serine, threonine and tyrosine), phosphoramidates (histidine, arginine and lysine), acylphosphates (aspartate and glutamate), and thiophosphate (cysteine). Reversible, multisite phosphorylation of protein Ser, Thr and Tyr residues mediates numerous signal transduction pathways in eukaryotic (Cohen, 2000) and prokaryotic (Deutscher \& Saier, 2005) cells. Histidine and cysteine phosphorylation are well known critical processes involved in a bacterial phosphoenolpyruvate-dependent carbohydrate transport system (Meadow et al., 1990; Stadtman, 1994). Aspartate residue acts as a phosphate acceptor in P-type ATPases (Post \& Kume, 1973) and certain class of phosphotransferases (Collet et al., 1998). Histidine and aspartate phosphorylations are engaged in two-component and multi-component phospho-relaying signalling systems in bacteria, fungi and plants (Stock et al., 2000; Kruppa \& Calderone, 2006; Grefen \& Harter, 2004), involved in linking an extracellular stimulus, such as changing osmolarity, oxygen, nitrogen, phosphorus or ethylene levels, to gene-regulating events. Such systems have not been discovered in higher eukaryotes, nevertheless it is becoming increasingly evident that histidine phosphorylation plays important regulatory roles also in mammalian cellular signal transduction (Matthews, 1995; Klumpp \& Krieglstein, 2002; Besant \& Attwood, 2005; Steeg et al., 2003; Tan et al., 2002; Kimura et al., 2000; Kowluru, 2003; 2008). Reports regarding the presence and significance of arginine and lysine phosphorylation in proteins are sparse and mainly concern histones. We have not found any reports about glutamate phosphorylation in proteins.

The majority of protein phosphorylation research has been focused on Ser, Thr and Tyr, i.e. phosphomonoesters that are acid-stable and may be studied by methods involving acidic treatments commonly used in phosphoprotein and phosphopeptide analysis. In contrast, phosphoramidates, i.e. phosphohistidine, phosphoarginine and phospholysine, are susceptible to hydrolysis under acidic conditions, and therefore these posttranslational modifications generally are overlooked in conventional studies of protein phosphorylation.

The objectives of the present paper are: (i) to overview our current knowledge on the occurrence of phos-

\footnotetext{
« e-mail j.ciesla@nencki.gov.pl

*Present address: Institute of Biochemistry and Biophysics, Polish Academy of Sciences, Warszawa, Poland

Abbreviations: GPRC, G protein-coupled receptor; KCa3.1, potassium channel; NDPK, nucleoside diphosphate kinase; PHP or PHPT1, phosphohistidine phosphatase
} 
Table 1. Proteins phosphorylated on histidine residue(s)

\begin{tabular}{|c|c|}
\hline Proteins & References \\
\hline \multicolumn{2}{|l|}{ Intermediate forms of enzymes } \\
\hline $\begin{array}{l}\text { Bacterial phosphoenolpyruvate-sugar phosphotransferase system } \\
\text { (PTS) }\end{array}$ & Meadow et al., 1990; Stadtman, 1994 \\
\hline $\begin{array}{l}\text { Two-component and multi-component phospho-relay signalling } \\
\text { systems in bacteria, fungi and plants }\end{array}$ & Stock et al., 2000; Grefen \& Harter, 2004; Kruppa \& Calderone, 2006 \\
\hline Nucleoside diphosphate kinases & Kowluru \& Metz, 1994; Wålinder, 1968; Kimura et al., 2000 \\
\hline Heat shock protein Hsp70 & Lu et al., 2006 \\
\hline Proteasome $20 \mathrm{~S}$ & Yano et al., 1999 \\
\hline Succinyl-CoA synthetase & Boyer et al., 1962 \\
\hline ATP-citrate lyase & $\begin{array}{l}\text { Williams et al., 1985; Robertson et al., 1988; Krivanek \& Novakova, } \\
1991\end{array}$ \\
\hline Human prostatic acid phosphatase & Ostrowski 1978; McTigue \& Van Etten, 1978 \\
\hline Glucose-6-phosphatase & Feldman \& Butler, 1969; Ghosh et al., 2004 \\
\hline 6-Phosphofructo-2-kinase/fructose-2,6-bis-phosphatase & Pilkis et al., 1983; Mizoguchi et al., 1999 \\
\hline Phosphoglycerate mutase & Rose, 1970 \\
\hline Phospholipase D superfamily & Gottlin et al., 1998 \\
\hline Most likely more proteins & Lott et al., 2006 \\
\hline \multicolumn{2}{|l|}{ Proteins phosphorylated by protein histidine kinases } \\
\hline Histone $\mathrm{H} 4$ & Chen et al., 1974 \\
\hline Heterotrimeric G-proteins & Wieland et al., 1991; 1993 \\
\hline Potassium channel KCa3.1 & Srivastava et al., 2006 \\
\hline Annexin 1 & Muimo et al., 2000 \\
\hline P-selectin & Crovello et al., 1995 \\
\hline Thymidylate synthase & Frączyk et al., 2009 \\
\hline
\end{tabular}

phorylated basic amino acid residues (His, Arg, Lys) in proteins and the role of such modifications in cell functioning, and (ii) to indicate methodological limitations of studies on phosphorylation of basic amino acids.

\section{PROTEINS PHOSPHORYLATED ON HISTIDINE}

There are two biologically relevant phosphohistidine isomers - the phosphoryl group may be linked to N-1 $\left(\mathrm{N}^{\pi}\right)$ or N-3 $\left(\mathrm{N}^{\tau}\right)$ of the His residue (Attwood et al., 2007 and references there, Fig. 1). The phosphohistidine phosphoramidate bond has a large negative standard free energy $\left(\Delta G^{\circ}=\sim-12\right.$ to $\left.-14 \mathrm{kcal} / \mathrm{mol}\right)$ of hydrolysis and therefore is less stable than phosphoester bonds in phosphohydroxyamino acids in proteins $\left(\Delta G^{\mathrm{o}}=-6.5\right.$ to $9.5 \mathrm{kcal} / \mathrm{mol}$ (Hultquist, 1968; Stock et al., 1990). However, in proteins the stability of phos-
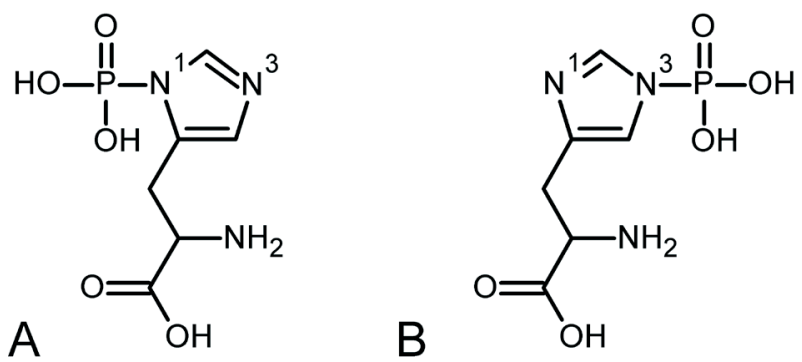

Figure 1. Structures of N-1-phosphohistidine (A) and N-3-phosphohistidine (B) phoramidate bond depends on the neighboring aminoacid residues (Waygood et al., 1985; Kim et al., 1993; Lott et al., 2006). It has also been postulated that at acidic $\mathrm{pH}$ in the cellular microenvironment, the labile nature of this bond might be used in a system that requires an on/off switch without the need for participation of protein phosphatases (Klumpp \& Krieglstein, 2002). It should be noted, however, that a mammalian protein histidine phosphatase (PHP) has been identified (Ek et al., 2002; Klumpp et al., 2002). It is estimated that about $6 \%$ of protein phosphorylation in eukaryotes concerns histidine residues, thus this modification is much more frequent than tyrosine phosphorylation (Matthews, 1995). In most cases protein phosphohistidine residues are found in intermediate forms of enzymes whose catalytic activities involve transfer of high-energy phosphoryl groups to other molecules via a phosphohistidine intermediate, however, there is also another category of phosphohistidine-containing proteins: those that do not autophosphorylate, but are phosphorylated by protein histidine kinases (Table 1).

In this chapter we focus on the latter group of proteins, emphasizing the possible regulatory role of this posttranslational modification.

\section{Histone H4}

Histones are small basic proteins associated with DNA. The four histones termed $\mathrm{H} 2 \mathrm{~A}, \mathrm{H} 2 \mathrm{~B}, \mathrm{H} 3$ and $\mathrm{H} 4$ form an octameric protein core around which DNA is wound in the basic nucleosome structure of chromatin. Another member of the histone family, histone $\mathrm{H} 1$, is 
bound to the outside of the core and "locks" the DNA into position. Various posttranslational modifications of histones, such as acetylation, methylation, phosphorylation, ribosylation and ubiquitination may affect transcription (for review, see Khorasanizadeh, 2004). Histone H4 undergoes acetylation on Lys5,8,12 and 16, phosphorylation on Ser1 and phosphorylation on His18 and His75. It was the first vertebrate protein identified to contain phosphorylated histidine residues. The formation of histone $\mathrm{H} 4$ histidine phosphate has been observed in vivo $18 \mathrm{~h}$ after partial hepatectomy in rats and correlated with DNA synthesis (Chen et al., 1974). The first and well characterized histone $\mathrm{H} 4$ histidine kinase was purified from yeast (Huang et al., 1991). In vitro it phosphorylates specifically His75, but not His18, to form N-1phosphohistidine. Other histone $\mathrm{H} 4$ histidine kinases have been detected in regenerating rat liver (Smith et al., 1973; Chen et al., 1977; Tan et al., 2004), in fetal rat and human liver (Tan et al., 2004), human hepatocarcinoma tissue (Tan et al., 2004), Walker-256 carcinoma cells (Smith et al., 1974), pancreatic $\beta$-cells (Kowluru, 2002) and thymus (Besant \& Attwood, 2000). The histone kinases from regenerating rat liver and Walker-256 carcinoma cells appear to phosphorylate His75 and His18 in histone $\mathrm{H} 4$, respectively, resulting in formation of $\mathrm{N}-1$ phosphohistidine in the former and N-3-phosphohistidine in the latter case. The histone $\mathrm{H} 4$ histidine phosphorylation appears to be also an in vivo phenomenon, as proteolytic digestion of phosphorylated histone fractions from regenerating rat liver after in vivo administration of ${ }^{32}$ P-labelled sodium phosphate showed H4 phosphohistidine (Chen et al., 1974). Interestingly, in regenerating rat livers, phosphohistidine was not formed on de novo synthesized H4 molecules, but exclusively on those preexisting before a peak of DNA synthesis, as was shown in livers of rats injected with $\left[{ }^{3} \mathrm{H}\right]$ histidine and ${ }^{32} \mathrm{P}_{\mathrm{i}} 18 \mathrm{~h}$ after partial hepatectomy (Chen et al., 1977). The turnover of the P-N linkages in $\mathrm{H} 4$ was apparently rapid, with an approximate life-time of $2 \mathrm{~h}$ (Chen et al., 1977). These data, coupled with the coincidence of the increase in H4 kinase activity with DNA synthesis and cell proliferation (Chen et al., 1974), suggest a physiological role of histone $\mathrm{H} 4$ histidine phosphorylation during DNA replication. It is possible that this modification, occurring at the time when histones are displaced from DNA during replication, prevents premature formation of nucleosome complexes during DNA synthesis (Besant et al., 2003). Nickel and copper were reported to bind to His18 of histone H4 (Zoroddu et al., 2000), pointing to the possibility of a more general carcinogenesis pathway. Nickel was found to decrease histone H4 Lys12 acetylation in mammalian cells, which may represent a positional effect of His18 phosphorylation (Broday et al., 2000). If the His18 phosphorylation alters $\mathrm{H} 4$ acetylation, it may be expected to affect gene expression pattern.

Unfortunately, even when histidine phosphorylation is detected, it is not a trivial task to identify its biological consequences, therefore no conclusive evidence has been found so far in support of these postulated roles of H4 histidine phosphorylation.

As regards the reverse reaction, i.e. histidine dephosphorylation, histone $\mathrm{H} 4$ phosphorylated by yeast histidine kinase on His 75 has been found to be a substrate for Ser/Thr protein phosphatases 1, 2A and 2C from rabbit skeletal muscles (Kim et al., 1993), rat liver and spinach leaves (Matthews \& Mackintosh, 1995), but nothing is known yet on enzymatic histone $\mathrm{H} 4$ histidine dephosphorylation in vivo.

\section{Heterotrimeric G-proteins}

Numerous G-proteins, comprising the $\alpha, \beta$ and $\gamma$ subunits, coupled to a large variety of transmembrane receptors ( $G$ protein-coupled receptor, GPRC), are components of the most widely used signalling system in mammalian cells (Wettschureck \& Offermanns, 2005). Binding of an extracellular agonist (biogenic amines, amino acids, ions, lipids, peptides, proteins and other agents) to GPRC causes conformational changes of the receptor protein which in turn transduces this information to the respective heterotrimeric $G$ protein (Gilman, 1987). Receptor-mediated activation of the $G$ protein $\alpha$-subunit involves an exchange of bound GDP for GTP and dissociation of the GTP-bound $\alpha$-subunit, with both the activated $\alpha$-subunit and the $\beta \gamma$ dimer capable of regulating downstream targets (adenylate cyclase, phosphodiesterase and several forms of phospholipases) to bring about biological responses, such as, among others, proliferation, cell survival, differentiation, migration, angiogenesis, metastasis.

Recent data suggest that there are also alternative, GPRC-independent ways of $G$ protein activation. One of them uses a special class of proteins (activators of Gprotein signalling, AGS) directly interacting with G-protein $\alpha$-subunits and $\beta \gamma$ dimers and activating this signalling pathway (Blumer et al., 2007), and another involves phosphorylation of histidine residue in the protein. The $G$ protein $\beta$ subunit of heterotrimeric $G$ proteins has been found to be phosphorylated on histidine in various tissues (Wieland et al., 1993; Kowluru et al., 1996; Cuello et al., 2003; Hippe et al., 2003). Apparently, nucleoside diphosphate kinase (NDPK) B forms a complex with the $G$ protein and phosphorylates its $\beta$ subunit at His266. The high-energy phosphate can then be transferred onto GDP and the formed GTP subsequently activates stimulatory $G \alpha_{\mathrm{s}}$ and inhibitory $G \alpha_{\mathrm{i}}$ proteins (Wieland et al., 1991; 1992; 1993; Cuello et al., 2003; Hippe et al., 2003). It is interesting that nucleoside diphosphate kinases (NDPKs) have long been thought to be housekeeping enzymes that solely catalyze, through a highenergy P-His118 intermediate, the transfer of terminal phosphate groups from 5'-triphosphate to 5'-diphosphate nucleosides, and thus play a key role in nucleotide metabolism. In mammalian tissues NDPKs are encoded by the $n m 23$ gene family. Various combinations of subunits in heterohexamers yield nine isoforms. Two of them, NDPK $A$ and NDPK B (also known as Nm23H1 and $\mathrm{Nm} 23 \mathrm{H} 2$, respectively), have been identified to serve as protein kinases to phosphorylate various substrates on His, Asp, Ser and Thr residues (Engel et al., 1995; reviewed in Steeg et al., 2003; Besant \& Attwood, 2005; Klumpp \& Krieglstein, 2009) and increasingly appear to act as signalling molecules (reviewed in Kimura et al., 2000; 2003; Roymans et al., 2002; Kowluru, 2008; Wieland et al., 2010; Mehta \& Orchard, 2010).

In cardiomyocytes, classical activation of $G \alpha_{\mathrm{s}}$ and $G \alpha_{\mathrm{i}}$ proteins through GPRCs regulates intracellular cAMP levels that control myocardial contractility by activation of the protein kinase A pathway and alteration in $\mathrm{Ca}^{2+}$ transients (Bers, 2002; Rockman et al., 2002). The GPRC-independent activation of a $G$ protein signalling pathway involving $G$ protein $\beta$ subunit His266 phosphorylation appears to have a physiological role in regulation of basal cAMP production. Recombinant G $\beta \gamma$ dimer, carrying His266Leu mutation on $\beta$ subunit (deficient in intermediate $G \beta$ phosphorylation, but not interfering with the heterotrimers activation via classical receptoragonist mechanism), integrated into heterotrimeric $G$ 
proteins and overexpressed in rat cardiomyocytes, suppressed basal cAMP formation by up to $55 \%$, as compared with wild-type G $\beta \gamma$. A similar effect was obtained by siRNA-mediated NDPK knockdown (Hippe et al., 2007). It is also worth adding that in the membrane fraction of failing myocardium a relative enrichment for NDPK was observed, although the total NDPK level appeared unchanged. Increased membrane-associated NDPK levels run parallel with the progression of cardiac hypertrophy induced by chronic $\beta$-adrenergic receptor stimulation (Lutz et al., 2003). It has been speculated that this may lead to enhanced formation of basal cAMP and thereby contribute to progression of the disease (Engelhardt \& Rochais, 2007).

A mechanism for alternate, GPRC-independent activation of trimeric $G$ proteins in the pancreatic $\beta$-cell, has also been proposed by Kowluru and coworkers (Kowluru 2008; 2003; Kowluru et al., 1996). In the context of physiological, glucose-induced insulin secretion, one of the histone H4-phosphorylating histidine kinases or NDPK phosphorylates the G $\beta$ subunit on a histidine residue. This phosphate, in turn, is relayed to the GDP bound to the $G \alpha$ subunit to yield an active GTP-bound $G$ protein. It is proposed that such a mechanism is similar to the classical ping-pong mechanism of activation of NDPK. Following this, the $\mathrm{G} \alpha$ subunit dissociates and both GTP-bound $G \alpha$ and the $G \beta \gamma$ dimer regulate various effector proteins. However, some experimental data argue against a direct transfer of the phosphate from PHis266 in the G $\beta$ subunit onto G $\alpha$-bound GDP (Hohenegger et al., 1996) and recent evidence suggests that the high-energy phosphate is specifically transferred onto free GDP, locally forms GTP which binds to and thereby activates the respective $G$ protein $\alpha$ subunit (discussed in Wieland, 2007). On one hand, $G$ protein $\beta$ subunit may serve only as a simple high energy phosphate relay, but on the other, His266 phosphorylation may alter $G$ protein $\beta$ subunit function in a yet to be determined fashion.

The first identified eukaryotic phosphohistidine phosphatase (PHP) (Hermesmeier \& Klumpp, 1999; Ek et al., 2002; Klumpp et al., 2002) was found to specifically dephosphorylate P-His in the G $\beta$ subunit (but not NDPK $B$ ) of the retinal $G$ protein transducin, as well as phosphorylated $G \beta$ in membranes of $\mathrm{H} 10$ cells. Additionally, stable overexpression of PHP in H10 cells led to a strong reduction of phosphate incorporated into $G \beta$, but not into NDPK, in those cells (Mäurer et al., 2005). Thus PHP might be an endogenous regulator of NDPKdependent $G$ protein activation.

\section{Potassium channel KCa3.1}

KCa3.1 is a component of an intermediate conductance $\mathrm{Ca}^{2+}$-activated $\mathrm{K}^{+}$channel, expressed in $\mathrm{T}$ and $\mathrm{B}$ cells, epithelial cells and smooth muscle cells. By mediating the efflux of $\mathrm{K}^{+}$, the channel functions to keep a negative membrane potential, which is required to maintain a favorable electrochemical gradient for $\mathrm{Ca}^{2+}$ influx. An increase in cytosolic $\mathrm{Ca}^{2+}$ triggers events leading to the transcription of a number of genes. KCa3.1 channels are rapidly upregulated after $\mathrm{T}$ cell activation, and are required for maximal $\mathrm{Ca}^{2+}$ influx and proliferation during the reactivation of naive $T$ cells (Cahalan et al., 2001).

Aside from the requirement of binding of $\mathrm{Ca}^{2+}$ to the calmodulin bound to carboxy terminus of KCa3.1, the channel also needs phosphatidylinositol 3-phosphate $\mathrm{PI}(3) \mathrm{P}$ for activation. The effect of $\mathrm{PI}(3) \mathrm{P}$ is mediated via 14 amino acids in the same carboxy terminus of KCa3.1 (Srivastava et al., 2006a). Recent elegant studies of Srivastava and coworkers have shown that phosphorylation of a histidine residue of the channel protein regulates its activation in CD4 T cells (Srivastava et al., 2006). Screening of a yeast two-hybrid library demonstrated the binding of nucleoside diphosphate kinase B to KCa3.1 carboxy terminus containing the 14 amino acids (the same as those necessary for PI(3)P action). Immunoprecipitation experiments confirmed the specific interaction of endogenous NDPK B and endogenous KCa3.1 in human CD4 T cells. NADPK B expression in $\mathrm{CHO}$ cells overexpressing KCa3.1 increased the channel amplitude, as assessed by whole-cell patch-clamp experiments. In addition, the kinase activity of NDPK B was crucial for this activation because expression of a mutated NADPK B (His118, required for the kinase activity, was replaced by Asn) did not activate KCa3.1. The target for NDPK $\mathrm{B}$ phosphorylation turned out to be His358 within the 14 amino acid carboxy terminus of KCa3.1 metioned above, as shown in inside/out membrane patches. Experiments with the use of siRNA to silence NDPK B led to a marked inhibition of KCa3.1 channel activity, $\mathrm{Ca}^{2+}$ influx and proliferation of human CD4 T lymphocytes and provided genetic evidence that NADPK $\mathrm{B}$ is required for full activation of the channel and subsequent reactivation of CD4 $\mathrm{T}$ cells. According to the authors (Srivastava et al., 2006), the 14 amino acids of the KCa3.1 carboxy terminus account for the distinct regulation by $\mathrm{PI}(3) \mathrm{P}$ by binding and recruiting NDPK $\mathrm{B}$ to the KCa3.1 channel. Once bound, NDPK B directly phosphorylates His358, which relieves the inhibitory effect of these 14 amino acid on the channel activity, leading to channel activation. However, the relationship between PI(3)P, NDPK B and KCa3.1 activation requires further studies.

Srivastava and coworkers have also provided evidence for negative regulation of CD4 T cells through dephosphorylation of His358 in KCa3.1 by protein histidine phosphatase PHPT-1 (Srivastava et al., 2008). PHPT-1 is the phosphatase demonstrated to dephosphorylate PHis 266 in $G$ protein $\beta$ subunit and ATP-citrate lyase, named there PHP (Klumpp \& Krieglstein, 2005, 2009). Using the same methods as for studying His358 phosphorylation of KCa3.1 by NDPK B, the authors demonstrated PHPT-1 to inhibit KCa3.1 channel activity, with the enzyme's phosphatase activity being necessary for this inhibition. They showed direct binding of PHPT-1 and KCa3.1 in HEK 293 cells and direct inhibition of KCa3.1 channel activity in isolated membrane patches. In vitro PHPT-1 dephosphorylated KCa3.1 P-His358, phosphorylated by NDPK B, but not NADPK B autophosphorylated on His118. Silencing PHPT-1 by siRNA in primary CD4 $\mathrm{T}$ cells led to increased $\mathrm{KCa} 3.1$ channel activity and $\mathrm{T}$ cell receptor-dependent stimulated calcium influx and proliferation.

Even though an attempt to detect histidine-phosphorylated KCa3.1 in vivo, in cells labelled with orthophosphate, has failed (Srivastava et al., 2008), it seems that so far the KCa3.1 channel is the best example of regulation of a biological function in mammalian cells by reversible histidine phosphorylation.

\section{Annexin 1}

Annexin 1 is a member of a superfamily consisting of 13 calcium- or calcium- and phospholipidsbinding proteins sharing high biological and structural 
homology (Raynal \& Pollard, 1994). Each member of the superfamily has a core domain where calcium- or phospholipids-binding consensus lies. The N-terminus, unique to each annexin, with varying amino-acid sequence and length, is thought to be responsible for the biological activity and specific function of these proteins. Their main biochemical feature is, in theory, the binding to phospholipid membranes in a calcium-dependent manner. Annexin 1, the first described member of this superfamily, originally known as macrocortin (Blackwell et al., 1980), is ascribed many important roles, among them membrane aggregation, antiinflammatory function, fagocytosis, regulation of cell proliferation, differentiation and apoptosis, and possible contribution to tumor development and progression (reviewed in Lim \& Pervaiz, 2007; and Rescher \& Gerke, 2004). The 49-amino acid N-terminus of annexin 1 is the regulatory region, undergoing phosphorylation on serine, threonine and tyrosine residues (Raynal \& Pollard, 1994; Rothhut, 1997; Solito et al., 2006; Dorovkov \& Ryazanov, 2004; Mulla et al., 2004) and proteolysis (Seemann et al., 1997).

There is also a report on annexin 1 histidine residue(s) phosphorylation, with GTP or ATP as phosphate donor (Muimo et al., 2000). The annexin 1 His phosphorylation, in contrast to other posttranslational modifications of the protein, occurs on the C-terminus, which localizes it to the core domain. As the proposed functions of the core include membrane organization and aggregation (Donnelly \& Moss, 1997; Gerke \& Moss, 1997), an altered charge on histidine may affect these functions. It is also possible that phosphohistidine may initiate annexin 1 cleavage and thus generate active peptide fragments, or lead to further degradation of the protein (Muimo et al., 2000).

Annexin 1 histidine phosphorylation is inhibited by cAMP, shown to bind to the protein C-terminus at a site adjacent to conserved His103, alter annexin 1 membrane aggregating and abolish its ability to act as a calcium channel in artificial lipid bilayers (Cohen et al., 1995; Muimo et al., 2000). On the other hand, cAMP may also bind directly to the histidine kinase and allosterically regulate its activity or act through a yet unknown pathway (Muimo et al., 2000).

Phosphorylation of histidine residue has recently been proposed as a latent common mechanism for signaling of intracellular chloride concentration to proteins within the apical membrane of respiratory epithelia (Treharne et al., 2006). In the apical fraction from sheep tracheal epithelium Muimo and coworkers have identified the first protein underlying the phosphorylation cascade, i.e. NDPK, whose $\mathrm{Cl}^{-}$-dependent phosphorylation precedes phosphorylation of most other histidine-phosphorylated proteins in this system, such as annexin 1 (Muimo et al., 1998; 2000). Annexin 1 and NDPK do not undergo phosphorylation in an ion-dependent manner when purified to homogeneity but require interactions within apical membrane environment to become chloride "sensors". Moreover, phosphatases could also play a role, because phosphatase inhibiton with phosphorothioate nucleotide analogues (but not with classical phosphatase inhibitors, such as okadaic acid) alter the net of phosphoprotein profile of the apical membrane (Treharne et al., 2006).

Thus the presence of a novel regulatory pathway, involving histidine residue phosphorylation and annexin 1, is suggested.

\section{P-selectin}

P-selectin is an adhesion receptor of platelets and endothelial cells, which mediates the interaction with neutrophils and monocytes (Larsen et al., 1989). The protein resides in the membrane of $\alpha$ granule, but upon platelet activation and degranulation is rapidly translocated to the plasma membrane, where it becomes activated and in turn activates certain metabolic pathways and morphological changes. P-selectin is composed of a lectin domain, an epidermal growth factor domain, a series of consensus repeat domains, a transmembrane region and a C-terminal cytoplasmic tail Johnston et al., 1989). Platelet activation is accompanied by phosphorylation of the cytoplasmic tail of P-selectin on Ser, Thr and Tyr residues (Crovello et al., 1993; Fujimoto \& McEver, 1993). Rapid phosphorylation and selective dephosphorylation of specific amino acids may be important for P-selectin function and signal transduction within the platelets (Crovello et al., 1993).

Crovello and coworkers have demonstrated that Pselectin phosphorylation during activation of human platelets by thrombin or collagen includes also a transient generation of both P-His771 and P-His773 on the C-terminal tail (Crovello et al., 1995) that was unnoticed during previous P-selectin phosphorylation research. Thrombin is known to initiate a distinct signalling pathway through the thrombin receptor (Coughlin, 1994), with the thrombin-induced platelet activation being rapid and complete in $60 \mathrm{~s}$, whereas collagen activates platelets via an independent mechanism involving binding to, among other factors, glycoprotein Ia-IIa and

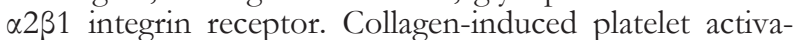
tion is less potent, with the duration time of the order of several minutes. The kinetics of phosphorylation/dephosphorylation of histidine residues in P-selectin from thrombin- or collagen-induced platelets paralleled the rate of respective platelet activation and was simultaneous with Ser/Thr/Tyr phosphorylation. Since P-selectin is unlikely to undergo autophosphorylation on histidines because of its short cytoplasmic tail, the histidine kinase(s) and phosphatases(s) involved remain to be identified.

The function of transient histidine phosphorylation in P-selectin, and possibly in other proteins, during platelet activation remains to be elucidated.

\section{Thymidylate synthase}

Thymidylate synthase catalyzes de novo synthesis of thymidylate, necessary for DNA replication and repair, and thus cell proliferation (reviewed in Carreras and Santi, 1995; Costi et al., 2005). Thymidylate synthase isolated from L1210 mouse leukemia parental and 5'-fluorodeoxyuridine-resistant cells showed significant difference in sensitivity to the slow-binding inactivation by 5-fluoro-dUMP which was not due to the corresponding gene mutations (Cieśla et al., 2006). In view of a previous report on possible phosphorylation of the enzyme in cultured rat cells (Samsonoff et al., 1997), such a modification was sought by conventional mass spectrometry of isoelectric focusing fractions of native proteins of the two enzyme forms. Surprisingly, phosphorylation of Ser10 and Ser16 was found, but only in the resistant cell enzyme (Frączyk et al., 2009), although staining of proteins separated by SDS/PAGE with the Pro-Q ${ }^{\circledR}$ Diamond Phosphoprotein Gel Stain showed phosphorylation of the enzyme forms from both cell lines (Cieśla et al., 2006). One possibile explanation of this apparent 
discrepancy is that at least the enzyme from the parental cells is phosphorylated on basic amino acids, which escaped detection by the former procedure. A similar problem appeared during studies of four recombinant enzyme preparations (human, rat, mouse and Trichinella spiralis thymidylate synthases), whose phosphorylation could be demonstrated by Pro-Q ${ }^{\circledR}$ Diamond staining, but not by conventional MS analysis. However, ${ }^{31} \mathrm{P}$ NMR spectra showed the presence of phosphohistidine residues in phosphorylated fraction enriched from each of the recombinant enzyme preparations (Frączyk et al., 2009). Interestingly, the phosphorylation of the enzyme's His residue(s) affected not only its catalytic (by lowering the $V_{\max }$ app values), but also non-catalytic (by affecting repression of the enzyme's own mRNA in vitro translation) properties (Frączyk et al., 2009).

The possible function(s) of the phosphorylation of thymidylate synthase is of obvious interest but, as with many other phosphorylated proteins (Lienhard, 2008), further studies are needed to learn more about it.

\section{PROTEINS PHOSPHORYLATED ON ARGININE AND LYSINE}

While there has been ample research concerning protein arginine and lysine modifications, such as methylation, acetylation, citrullination, SUMOylation and ubiquitination, especially with reference to histones, where combinatorial action of these posttranslational modifications regulates critical DNA processes, including replication, repair and transcription (reviewed in Khorasanizadeh, 2004), protein Arg and Lys phosphorylation has been studied considerably less frequently. Additionally, beside experimental difficulties in phosphoramidate research, phosphoarginine and phospholysine appear to be present much less frequently than phosphohistidine. Nevertheless, several sporadic and one well-documented report have evidenced the occurence of phosphoarginine and phospholysine in proteins. A few kinases and phosphatases that act on arginine and lysine residues have been found in various eukaryotic tissues (Ohmori et al., 1993; Wong et al., 1993; Kumon et al., 1996; for review, see Matthews, 1995, Besant et al., 2009).

\section{Histones $\mathrm{H} 1$ and $\mathrm{H} 3$}

Considering the presence of phosphoramidates in histones, not only histidine (in histone $\mathrm{H} 4$; see above) but also arginine and lysine (Fig. 2) were found phosphorylated. Acid-labile histone $\mathrm{H} 1$ phosphates were formed in vivo $18 \mathrm{~h}$ after partial hepatectomy in rats, which correlated with the onset of DNA synthesis (Chen et al., 1974). Regenerating rat liver nuclei contain two histone kinases producing acid-labile histone phosphates, one active at $\mathrm{pH} 6.5$, and the other at $\mathrm{pH}$ 9.5. The former kinase activity remained approximately constant during liver regeneration, whereas the latter increased at $12 \mathrm{~h}$, reached a peak at $18 \mathrm{~h}$, and began to decline $24 \mathrm{~h}$ after partial hepatectomy. Analysis of proteolytic digests of histone $\mathrm{H} 1$, isolated from regenerating liver revealed the presence of $\mathrm{N}^{\varepsilon}$-phospholysine. Administration of $\left[{ }^{3} \mathrm{H}\right]$ lysine and ${ }^{32} \mathrm{P}_{i}$ during liver regeneration showed that phospholysine was formed in some new and, presumably, some preexisting $\mathrm{H} 1$ molecules (Chen et al., 1977). Analysis of the formation of acidlabile (P-N) and acid-stable (P-O) linkages in nuclear proteins demonstrated the two processes to be equal-
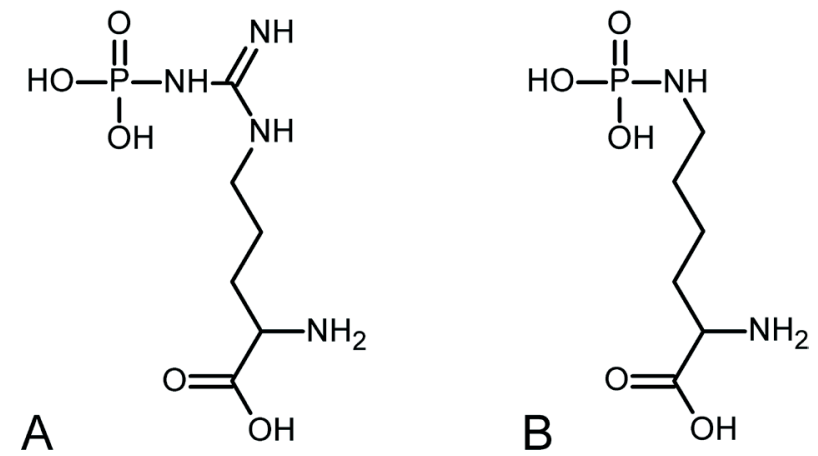

Figure 2. Structures of $N^{\omega}$-phosphoarginine (A) and $N^{\varepsilon_{-}}$ phospholysine (B).

ly common (Chen et al., 1974, 1977). The biological role of histone H1 Lys phosphorylation is not known. It may have functions similar to those postulated for other types of histone phosphates, e.g. contribution to gene activation, DNA replication or mitosis. Acidic non-histone proteins have also been found highly phosphorylated during liver regeneration, yielding both acid-labile (Lys and His) and acid-stable forms (Chen et al., 1974).

Ser10 and Ser28 residues in the N-terminal region of histone $\mathrm{H} 3$ have been proposed as mitosis-specific sites of phosphorylation involved in chromatin condensation (Shibata et al., 1990). However, those authors destroyed any potential phosphoramidate linkages by precipitating the phosphorylated protein with trichloroacetic acid. Wakim and Aswad (1994) showed histone H3 to undergo phosphorylation by a $\mathrm{Ca}^{2+}$-calmodulin-dependent kinase on four arginine residues (Arg2, 128, 129 and 131), three of them located within the C-terminus. It has been demonstrated by in vivo incorporation of ${ }^{32} \mathrm{P}$ into $\mathrm{H} 3$ in rat heart endothelial cells that phosphorylation of basic amino acid occurred in quiescent but not in dividing cells (Wakim et al., 1995). A Ca ${ }^{2+}$-calmodulin-dependent kinase, while present in nearly equal amounts in both quiescent and dividing cells, was activated 20-100-fold in quiescent cells. Those authors proposed that phosphorylation of histone $\mathrm{H} 3$ was involved in cell cycle exit in eukaryotes.

\section{Other proteins}

Phosphorylation on serine and threonine residues in myelin basic protein has been studied in a number of laboratories. Smith and coworkers examined the phosphorylation of myelin basic protein under $\mathrm{pH}$-neutral conditions and reported the occurrence of not only base-stable but also acid-labile phosphoryl bonds in myelin, the latter connected with the presence of phosphoarginine and phosphohistidine (Smith et al., 1976).

Phosphoarginine and phosphoserine were found in basic internal core protein, VP12, of granulosis virus infecting the Indian meal moth Plodia interpunctella (Wilson \& Consigli, 1985). The cyclic-nucleotide-independent protein kinase catalyzing the transfer of phosphate to both arginine and serine residues of VP12 has been localized to purified viral capsids. The authors believed this kinase to play a significant role in the viral replication cycle (Wilson \& Consigli, 1985).

An arginine-specific protein kinase tightly bound to DNA has been found in rat liver. The enzyme autophosphorylated and also phosphorylated a single chromosom- 
al $11-\mathrm{kDa}$ protein (also tightly bound to DNA) and viral capsidic protein VP12 (Levy-Favatier et al., 1987).

\section{IDENTIFICATION OF PHOSPHOHISTIDINE, PHOSPHOARGININE AND PHOSPHOLYSINE IN PROTEINS}

Several standard methods are employed to detect phosphorylated proteins, including sample fractionation, affinity purification, gel separation, immuno-based techniques, kinase/phosphatase activity assay, and various analytical procedures including mass spectrometry and ${ }^{31} \mathrm{P}$ NMR (for review, see Ross, 2007; Matthews, 1995; Fujitaki \& Smith, 1984; Besant \& Attwood, 2010). Phosphomonoesters (P-Ser, P-Thr, P-Tyr) are stable under acidic conditions and labile under alkaline conditions, except for phosphotyrosine, whereas phosphoramidates (P-His, P-Arg, P-Lys) are extremely acid-labile but relatively base-stable, except for arginine in hot alkali (Fujitaki \& Smith, 1984; Klumpp \& Krieglstein, 2002). Additionally, in contrast to phosphomonoesters, all phosphoramidates are unstable when exposed to neutral hydroxylamine or pyridine (DiSabato \& Jencks, 1961; Duclos et al., 1991). Histidine phosphorylation is inhibited by diethylpyrocarbonate and other histidine-specific reagents. Phosphocysteine is labile in slightly acidic conditions but is quite stable at very high or very low $\mathrm{pH}$ (Pigiet \& Conley, 1978). Acylphosphates (P-Asp, P-Glu) are, on the other hand, labile at either $\mathrm{pH}$ extreme (Koshland, 1952) and are cleaved by hydroxylamine (DiSabato \& Jencks, 1961). These features must be taken into account while using various techniques for phosphoprotein studying and may be employed for discrimination among phosphoproteins containing different types of phosphoamino acids. Since the majority of conventional techniques involve acidic treatment, they have to be adapted for use for phosphoramidate identification or several alternative experimental approaches may be utilized: (i) partial alkali hydrolysis to reduce the relative abundance of base-labile P-Ser and P-Thr (Chen et al., 1974; Besant \& Attwood, 1998), (ii) dialysis methods of assaying for acid lability (Fujitaki et al., 1981), (iii) extraction methods for determination of phosphomonoesters to phosphoramidates ratio (see Fujitaki \& Smith, 1984 and references there), (iv) neutral or basic polyacrylamide gel electrophoresis (Hardison \& Chalkley, 1978; Fujitaki \& Smith, 1984), (v) staining with commercially available phosphoprotein-specific fluorescent stain Pro- $\mathrm{Q}^{\circledR}$ Diamond, (vi) HPLC (Steiner et al., 1980; Matthews \& Wei, 1991; Zu et al., 2007), (vii) reversed-phase column chromatography (Tan et al., 2003), (viii) reversed-phase TLC (Besant et al., 2000), (ix) thin-layer silica chromatography (Hess et al., 1988), (x) thin-layer electrophoresis (Besant \& Attwood, 2000), (xi) mass spectrometry (Medzihradszky et al., 1997; Besant et al., 2000; Zu et al., 2007; Kleinnijenhuis et al., 2007; Lapek et al., 2011), (xii) ${ }^{31}$ P-NMR (Fujitaki et al., 1981). Both acidic conditions and high temperature should be avoided throughout the whole process of phosphorylation analysis. This means that neutral $\mathrm{pH}$ is favorable also during purification of the specific protein. On the other hand, applying gentler methods for detection of phosphorylation, such as ECD-MS, should improve the results (Kleinnijenhuis et al., 2007; Kowalewska et al., 2010).

Another option is to use, at least in in vitro studies, more stable analogues of phosphorylated basic amino acids, e.g. thiophosphoramidate analogue such as thiophosphohistidine, in which one of the oxygen atoms is replaced by the less electronegative sulfur atom. While substitution of sulfur for oxygen seems to cause a negligible steric/electronic perturbation to phosphohistidine, thiophosphohistidine is much more stable than phosphohistidine (Lasker et al., 1999; Pirrung et al., 2000; Ruman et al., 2009; 2010). Thiophosphorylation can be carried out either by the use of an engineered protein kinase, capable of consuming ATP $\gamma$ S (Allen et al., 2005; Carlson et al., 2010), or by chemical reaction with thiophosphoramidate (Lasker et al., 1999; Pirrung et al., 2000; Ruman et al., 2009; 2010). The latter method leads to a specific modification of the N-3 atom in the histidine side chain.

The usage of stable analogues of phosphorylated basic amino acids should help to solve another problem hampering studies on phosphoramidate-modified proteins. Since 1981, when the first antiphosphoamino acid antibody, capable of recognizing phosphotyrosine-containing proteins, was obtained from serum of rabbits immunized with benzonyl phosphonate conjugated to keyhole limpet hemocyanin (Ross et al., 1981), this new tool has been widely used in immunodetection of protein phosphorylation. Moreover, in 1991 phosphorylation state-specific (phospho-specific) antibodies were produced in rabbits following immunization with phosphorylated peptides of an amino-acid sequence identical with that encompassing the target protein phosphorylation site (Czernik et al., 1991). The latter created the possibility of specific recognition of the phospho-protein of interest. It should be noted, though, that commercial antiphosphoamino acid antibodies enabling qualitative and quantitative immunoassay of phosphoproteins as well as their concentration by immunoprecipitation or affinity chromatography, are only available thus far for specific proteins phosphorylated on hydroxy amino acids. Until very recently attempts to develop antibodies selective to a hapten containing phosphohistidine have been failing, presumably due to hydrolysis of such an immunogen being too fast to raise a strong immune response. Consequently, application of non-hydrolysable analogues of phosphorylated basic amino-acids appeared hopeful in this respect. One example of such a phosphohistidine analogue was phosphofurylalanine (Schenkels et al., 1999) but to our knowledge no reports appeared on its use as a hapten, and another was a pyrrole derivative analogous to phosphofurylalanine, that was successfully used to raise antibodies that were, unfortunately, selective for the analogue but not for phosphohistidine (Attwood et al., 2007). Only last year were Kee et al. (2010) successful in designing and synthesizing two phosphoryltriazolylalanine isomers as stable analogues of the two phosphohistidine isomers (1-P-His and 3-P-His). Of note is that both analogues were applied with success in solid-phase peptide synthesis and a synthetic peptide obtained this way, containing 3-P-His analogue, was used as an immunogen to raise rabbit polyclonal antibody selectively recognizing 3-PHis in full length histone $\mathrm{H} 4$ protein.

Of note, many commercially available anti-phosphotyrosine $\operatorname{IgGs}$ recognize also phosphohistidine. Taking into account that phosphohistidine may be 10 to 100 times more abundant than phosphotyrosine, this might provide a means to identify phosphohistidine in proteins. On the other hand, this phenomenon may also be misleading in the case of studies of phosphotyrosine.

Further problems with detecting phosphohistidine, phosphoarginine and phospholysine may result from a lack of commercially available standards (except for $\mathrm{N}^{\omega_{-}}$ phosphoarginine), although appropriate synthetic methods have been reported (Zetterquist \& Engström, 1967; Marcus \& Morrison, 1964; DeLuca et al., 1963). 
It is also important to bear in mind that denaturing buffers and phosphatase inhibitors normally used to suppress enzyme activity during protein extraction will most likely not guard against hydrolysis of phosphohistidine. The potential methodological obstacles encountered by researchers working on acid-labile protein phosphorylation are well presented in several previous reviews (Matthews, 1995; Wei \& Matthews, 1990; Klumpp \& Krieglstein, 2002; 2009; Besant \& Attwood, 1998; 2005; 2009; Besant et al., 2003; 2009; Steeg et al., 2003; Attwood et al., 2007; Ross, 2007; Kowluru, 2008; Zu et al., 2009).

In view of the difficulties in the analysis of phosphorylation of basic amino acids, the usage of in silico simulations should be considered useful, for example to predict the influence of phosphorylation on protein properties. Such a study with the use of molecular dynamics simulations allowed revealing the mechanism of the influence of Ser124 phosphorylation on the catalytic activity of human thymidylate synthase (Jarmula et al., 2010), and the same approach could be applied to study the consequences of phosphorylation of basic amino-acid residues, taking advantage of the force-field parameters calculated recently for phosphohistidine (Kosinsky et al., 2004; Homeyer et al., 2006).

\section{CONCLUSIONS}

Although the presence of phosphorylated basic amino-acid residues in proteins was recognized long time ago, it is often missed because of the short life-time and acid lability of the phosphoramidate bond and a lack of dedicated tools, such as specific antibodies, and therefore poorly studied. Surprisingly, for a long time phosphorylation of histidine (as well as lysine and arginine) residues in proteins and its role in signal transduction have been investigated and appreciated in prokaryotes but believed to be absent from eukaryotes, while phosphorylation of protein hydroxyamino acid (Ser, Thr, and Tyr) residues has been extensively studied in eukaryotes but believed not to occur in prokaryotes. As it now appears obvious that both types of protein phosphorylation play important roles in the functioning of both prokaryotic and eukaryotic cells, new tools and methods are necessary to intensify the studies on phosphorylation of protein basic amino-acid residues.

\section{Acknowledgements}

Supported by the Ministry of Science and Higher Education (grant number N N401 024 036).

\section{REFERENCES}

Allen JJ, Lazerwith SE, Shokat KM (2005) Bio-orthogonal affinity purification of direct kinase substrates. J Am Chem Soc 127: 5288-5289.

Attwood PV, Piggott MJ, Zu XL, Besant PG (2007) Focus on phosphohistidine. Amino Acids 32: 145-156.

Bers DM (2002) Cardiac excitation-contraction coupling. Nature 415: 198-205.

Besant PG, Attwood PV (1998) Problems with phosphoamino acid analysis using alkaline hydrolysis. Anal Biochem 265: 187-190.

Besant PG, Attwood PV (2000) Detection of mammalian histone H4 kinase that has yeast histidine kinase-like enzymic activity. Int J Biochem Cell Biol 32: 243-253.

Besant PG, Attwood PV (2005) Mammalian histidine kinases. Biochim Biophys Acta 1754: 281-290.

Besant PG, Attwood PV (2009) Detection and analysis of protein histidine phosphorylation. Mol Cell Biochem 329: 93-106.
Besant PG, Attwood PV (2010) Histidine phosphorylation in histones and in other mammalian proteins. Methods Enzymol 471: 403-426.

Besant PG, Lasker MV, Bui CD, Turck CW (2000) Phosphohistidine analysis using reversed-phase thin-layer chromatography. Anal Biochem 282: 149-153.

Besant PG, Tan E, Attwood PV (2003) Mammalian protein histidine kinases. Int J Biochem Cell Biol 35: 297-309.

Besant PG, Attwood PV, Piggott MJ (2009) Focus on phosphoarginine and phospholysine. Curr Protein Pept Sci 10: 536-550.

Blackwell GJ, Carnuccio R, Di Rosa M, Flower RJ, Parente L, Persico P (1980) Macrocortin: a polypeptide causing the anti-phospholipase effect of glucocorticoids. Nature 287: 147-149.

Blumer JB, Smrcka AV, Lanier SM (2007) Mechanistic pathways and biological roles for receptor-independent activators of $G$-proteins signaling. Pharmacol Ther 113: 488-506.

Boyer PD, Deluca M, Ebner KE, Hultquist DE, Peter JB (1962) Identification of phosphohistidine in digests from a probable intermediate of oxidative phosphorylation. I Biol Chem 237: 3306-3308.

Broday L, Peng W, Kuo M, Salnikow K, Zorrodu M, Costa M (2000) Nickel compounds are novel inhibitors of histone $\mathrm{H} 4$ acetylation. Cancer Res 60: 238-241.

Cahalan MD, Wulff H, Chandy KG (2001) Molecular properties and physiological roles of ion channels in the immune system. J Clin Immunol 21: 235-252.

Carlson HK, Plate L, Price MS, Allen JJ, Shokat KM, Marletta MA (2010) Use of semisynthetic epitope to probe histidine kinase activity and regulation. Anal Biochem 397: 139-143.

Carreras CW, Santi DV (1995). The catalytic mechanism and structure of thymidylate synthase. Annu Rev Biochem 64: 721-762.

Chen CC, Smith DL, Bruegger BB, Halpern RM, Smith RA (1974) Occurrence and distribution of acid-labile histone phosphates in regenerating rat liver. Biochemistry 13: 3785-3789.

Chen CC, Bruegger BB, Kern CW, Lin YC, Halpern RM, Smith RA (1977) Phosphorylation of nuclear proteins in rat regenerating liver. Biochemistry 16: 4852-4855.

Cieśla J, Frączyk T, Zieliński Z, Sikora J, Rode W (2006) Altered mouse leukemia L1210 thymidylate synthase, associated with cell resistance to 5 -fluoro-dUrd, is not mutated but rather reflects posttranslational modification. Acta Biochim Polon 53: 189-198.

Cohen P (2000) The regulation of protein function by multisite phosphorylation - A 25-year update. Trends Biochem Sci 25: 596-601.

Cohen BE, Lee G, Arispe N, Pollard HB (1995) Cyclic 3'-5'-adenosine monophosphate binds to annexin I and regulates calcium-dependent membrane aggregation and ion channel activity. FEBS Lett 377: 444-450.

Collet JF, Stoobant V, Pirard M, Delpierre G, Van Schaftingen E (1998) A new class of phosphotransferases phosphorylated on an aspartate residue in amino-terminal DXDX(T/V) motif. J Biol Chem 273: 14107-14112.

Costi MP, Ferrari S, Venturelli A, Calò S, Tondi D, Barlocco D (2005) Thymidylate synthase structure, function and implication in drug discovery. Curr Med Chem 12: 2241-2258.

Coughlin SR (1994) Molecular mechanisms of thrombin signaling. Semin Hematol 31: 270-277.

Crovello CS, Furie BC, Furie B (1993) Rapid phosphorylation and selective dephosphorylation of P-selectin accomopanies platelet activation. I Biol Chem 268: 14590-14593.

Crovello CS, Furie BC, Furie B (1995) Histidine phosphorylation of P-selectin upon stimulation of human platelets: a novel pathway for activation-dependent signal transduction. Cell 82: 279-286.

Cuello F, Schultze RA, Heemeyer F, Meyer HE, Lutz S, Jakobs KH, Niroomand F, Wieland T (2003) Activation of heterotrimeric Gproteins by a high energy phosphate transfer via nucleoside diphosphate kinase (NDPK) B and G $\beta$ subunits. Complex formation of NDPK B with G $\beta \gamma$ dimers and phosphorylation of His-266 in G $\beta$. J Biol Chem 278: 7220-7226.

Czernik AJ, Girault J-A, Nairn AC, Chen J, Snyder G, Kebabian J, Greengard P (1991) Production of phosphorylation state-specific antibodies. Methods Ensymol 201: 264-283.

DeLuca M, Ebner KE, Hultquist DE, Kreil G, Peter JB, Moyer R, Boyer PD (1963) The isolation and identification of phosphohistidine from mitochondrial protein. Biochem $Z$ 338: 512-525.

Deutscher J, Saier MH Jr (2005) Ser/Thr/Tyr protein phosphorylation in bacteria - for long time neglected, now well established. I Mol Microbiol Biotechnol 9: 125-131.

DiSabato G, Jencks WP (1961) Mechanism and catalysis of reactions of acyl phosphates. I. Nucleophilic reactions. I Am Chem Soc 83: 4393-4400.

Donnelly SR, Moss SE (1997) Annexins in the secretory pathway. Cell Mol Life Sci 53: 533-538.

Dorovkov MV, Ryazanov AG (2004) Phosphorylation of annexin I by TRPM7 channel-kinase. J Biol Chem 279: 50643-50646.

Duclos B, Marcandier S, Cozzone AJ (1991) Chemical properties and separation of phosphoamino acids by thin-layer chromatography and/or electrophoresis. Methods Ensymol 201: 10-21. 
Ek P, Pettersson G, Ek B, Gong F, Li JP, Zetterquist O (2002) Identification and characterization of a mammalian $14-\mathrm{kDa}$ phosphohistidine phosphatases. Eur J Biochem 269: 5016-5023.

Engel M, Veron M, Theisinger B, Lacombe M-L, Seib T, Dooley S, Welter C (1995) A novel serine/threonine-specific protein phosphotransferase activity of $\mathrm{Nm} 23$ /nucleoside diphosphate kinase. Eur J Biochem 234: 200-207.

Engelhardt S, Rochais F (2007) G proteins: more than transducers of receptor-generated signals? Circ Res 100: 1109-1111.

Feldman F, Butler FG (1969) Detection and characterization of the phosphorylated form of microsomal glucose-6-phosphatase. Biochem Biophys Res Commun 36: 119-125.

Frączyk T, Ruman T, Rut D, Dąbrowska-Maś E, Cieśla J, Zieliński Z, Sieczka K, Dębski J, Gołos B, Wińska P, Wałajtys-Rode E, Shugar D, Rode W (2009) Histidine phosphorylation, or tyrosine nitration, affect thymidylate synthase properties. Pteridines 20: 137-142.

Fujimoto T, McEver RP (1993) The cytoplasmic domain of P-selectin is phosphorylated on serine and threonine residues. Blood 82: 17581766.

Fujitaki JM, Smith RA (1984) Techniques in the detection and characterization of phosphoramidate-containing proteins. Methods Enzymol 107: 23-36.

Fujitaki JM, Fung G, Oh EY, Smith RA (1981) Characterization of chemical and enzymatic acid-labile phosphorylation of histone $\mathrm{H} 4$ using phosphorus-31 nuclear magnetic resonance. Biochemistry 20: 3658-3664.

Gerke V, Moss SE (1997) Annexins and membrane dynamics. Biochim Biophys Acta 1357: 129-154.

Ghosh A, Shieh J-J, Pan C-J, Chou JY (2004) Histidine 167 is the phosphate acceptor in glucose-6-phosphatase-3forming a phosphohistidine enzyme intermediate during catalysis. I Biol Chem 279: 12479-12483.

Gilman AG (1987) G proteins: transducers of receptor-generated signals. Annu Rev Biochem 56: 615-649.

Gottlin EB, Rudolph AE, Zhao Y, Matthews HR, Dixon JE (1998) Catalytic mechanism of the phospholipase D superfamily proceeds via a covalent phosphohistidine intermediate. Proc Natl Acad Sci USA 95: 9202-9207.

Grefen C, Harter K (2004) Plant two-component systems: principles, functions, complexity and cross-talk. Planta 219: 733-742.

Hardison R, Chalkley R (1978) Polyacrylamide gel electrophoretic fractionation of histones. Methods Cell Biol 17: 235-251.

Hermesmeier J, Klumpp S (1999) Histidine phosphatases activity in vertebrates. Pharm Med Chem 332: 34.

Hess JF, Bourret RB, Simon MI (1988) Histidine phosphorylation and phosphoryl group transfer in bacterial chemotaxis. Nature 336: 139-143.

Hippe HJ, Lutz S, Cuello F, Knorr K, Vogt A, Jakobs KH, Wieland $T$ (2003) Activation of heterotrimeric $G$ proteins by a high energy phosphate transfer via nucleoside diphosphate kinase (NDPK) $\mathrm{B}$ and $\mathrm{G} \beta$ subunits. Specific activation of Gs $\alpha$ by NDPK B. G $\beta \gamma$ complex in H10 cells. J Biol Chem 278: 7227-7233.

Hippe HJ, Luedde M, Lutz S, Koehler H, Eschenhagen T, Frey N, Katus HA, Wieland T, Niroomand F (2007) Regulation of cardiac cAMP synthesis and contractility by nucleoside diphosphate kinase $\mathrm{B} / \mathrm{G}$ protein $\beta \gamma$ dimer complexes. Circ Res 100: 1191-1199.

Hohenegger M, Mitterauer T, Voss T, Nanoff C, Freissmuth M (1996) Thiophosphorylation of the $G$ protein beta subunit in human platelet membranes: evidence against a direct phosphate transfer reaction to $\mathrm{G} \alpha$ subunits. Mol Pharmacol 49: 73-80.

Homeyer N, Horn AH, Lanig H, Sticht H (2006) AMBER force-field parameters for phosphorylated amino acids in different protonation states: phosphoserine, phosphothreonine, phosphotyrosine, and phosphohistidine. J Mol Model 12: 281-289.

Huang Y, Wei Y, Kim Y, Osterberg L, Matthews HR (1991) Purification of protein histidine kinase from yeast Saccharomyces cerevisiae. I Biol Chem 266: 9023-9031.

Hultquist DE (1968) The preparation and characterization of phosphorylated derivatives of histidine. Biochim Biophys Acta 153: 329-340.

Jarmuła A, Frączyk T, Cieplak P, Rode W (2010) Mechanism of influence of phosphorylation on serine 124 on a decrease of catalytic activity of human thymidylate synthase. Bioorg Med Chem 18: 33613370.

Johnston GI, Cook RG, McEver RP (1989) Cloning of GMP-40, a granule membrane protein of platelets and endothelium: sequence similarity to protein involved in cell adhesion and inflammation. Cell 56: $1033-1044$.

Kee J-M, Villani B, Carpenter LR, Muir TW (2010) Development of stable phosphohistidine analogues. I Am Chem Soc 132: 1432714329.

Khorasanizadeh S (2004) The nucleosome: from genomic organization to genomic regulation. Cell 116: 259-272.

Kim Y, Huang J, Cohen P, Matthews HR (1993) Protein phosphatases $1,2 \mathrm{~A}$ and $2 \mathrm{C}$ are protein histidine phosphatases. $J$ Biol Chem 268: 18513-18518.
Kimura N, Shimada N, Fukuda M, Ishijama Y, Miyazaki H, Ishii A, Takagi Y, Ishikawa N (2000) Regulation of cellular functions by nucleoside diphosphate kinase in mammals. J Bioenerg Biomembr 32: 309-315.

Kimura N, Shimada N, Ishijama Y, Fukuda M, Takagi Y, Ishikawa N (2003) Nucleoside diphosphate kinases in mammalian signal transduction systems: recent development and perspective. J Bioenerg Biomembr 35: 41-47.

Kleinnijenhuis AJ, Kjelsden F, Kalipolitis B, Haselmann KF, Jensen ON (2007) Analysis of histidine phosphorylation using tandem MS and ion-electron reactions. Anal Chem 79: 7450-7456.

Klumpp S, Krieglstein J (2002) Phosphorylation and dephosphorylation of histidine residues in proteins. Eur J Biochem 269: 1067-1071.

Klumpp S, Krieglstein J (2009) Reversible phosphorylation of histidine residues in proteins from vertebrates. Sci Signal 2: pe13.

Klumpp S, Hermesmeier J, Selke D, Bechmann G, van den Brulle J, Weidner G, Scharm B, Güssow D, Baumeister R, Kellner R, Krieglstein J (2002) Protein histidine phosphatase: a novel enzyme with potency for neuronal signaling. J Cereb Blood Flow Metab 22: 1420-1424.

Koshland DE Jr (1952) Effect of catalysts on the hydrolysis of acetyl phosphate. Nucleophilic displacement mechanisms in enzymatic reactions. J Am Chem Soc 74: 2286-2292.

Kosinsky YA, Volynsky PE, Lagant P, Vergoten G, Suzuki E, Arseniev AS, Efremov RG (2004) Development of the force field parameters for phosphoimidazole and phosphohistidine. J Comput Chem 25: 1313-1321.

Kowalewska K, Stefanowicz P, Ruman T, Frączyk T, Rode W, Szewczuk Z (2010) Electron capture dissociation mass spectrometric analysis of lysine-phosphorylated peptides. Biosci Rep. 30: 433-443

Kowluru A (2002) Identification and characterization of a novel protein histidine kinase in the islet $\beta$-cell: evidence for its regulation by mastoparan, an activator of $\mathrm{G}$-proteins and insulin secretion. Biochem Pharmacol 63: 2091-2100.

Kowluru A (2003) Regulatory roles for small G-proteins in the pancreatic beta cell: lessons from models of impaired insulin secretion. Am J Physiol Endocrynol Metab 285: E669-684.

Kowluru A (2008) Emerging roles for protein histidine phosphorylation in cellular signal transduction: lessons from the islet $\beta$-cell. $J$ Cell Mol Med 12: 1885-1908.

Kowluru A, Metz SA (1994) Characterization of nucleoside diphosphokinase activity in human and rodent pancreatic beta cells: evidence for its role in the formation of guanosine triphosphate, a permissive factor for nutrient-induced insulin secretion. Biochemistry 33: 12495-12503.

Kowluru A, Seavey SE, Rhodes CJ, Metz SA (1996) A novel regulatory mechanism for trimeric GTP-binding proteins in the membrane and secretory granule fractions of human and rodent beta cells. Biochem 313: $97-108$

Krivanek J, Novakova L (1991) ATP-citrate lyase is another enzyme the histidine phosphorylation of which is inhibited by vanadate. FEBS Lett 282: 32-34.

Kruppa M, Calderone R (2006) Two-component signal transduction in human fungal pathogens. FEMS Yeast Res 6: 149-159.

Kumon A, Kodama H, Kondo M, Yokoi F, Hiraishi H (1996) N ${ }^{\omega_{-}}$ phosphoarginine phosphatases $(17 \mathrm{kDa})$ and alkaline phosphatases as protein arginine phosphatases. J Biochem 119: 719-724.

Lapek JD, Tombline G, Friedman AE (2011) Mass spectrometry detection of histidine phosphorylation on NM23 H1. J Proteome Res. 10: $751-755$.

Larsen E, Celi A, Gilbert GE, Furie BC, Erban JK, Bonfanti R, Wagner DD, Furie B (1989) PADGEM protein: a receptor that mediates the interaction of activated platelets with neutrophils and monocytes Cell 59: 305-312.

Lasker M, Bui CD, Besant PG, Sugawara K, Thai P, Medzihradszky G, Turck CW (1999) Protein histidine phosphorylation: increased stability of thiophosphohistidine. Protein Sci 8: 2177-2185.

Levy-Favatier F, Depelch M, Kruh J (1987) Characterization of the arginine-specific protein kinase tightly bound to rat liver DNA. Eur J Biochem 166: 617-621.

Lienhard GE (2008) Non-functional phosphorylations? Trends Biochem Sci 33: 351-352.

Lim LKH, Pervaiz S (2007) Annexin 1: the new face of an old molecule. FASEB J 21: 968-975.

Lott JS, Paget B, Johnston JM, Delbaere LTJ, Sigrell-Simon JA, Banfield MJ, Baker EN (2006) The structure of an ancient conserved domain establishes a structural basis for stable histidine phosphorylation and identifies a new family of adenosine-specific kinases. $J$ Biol Chem 281: 22131-22141.

Lu Y, Hu Q, Yang C, Gao F (2006) Histidine 89 is an essential residue for Hsp70 in the phosphate transfer reaction. Cell Stress Chaperones 11: s148-153.

Lutz S, Mura RA, Hippe HJ, Tiefenbacher C, Niroomand F (2003) Plasma membrane-associated nucleoside diphosphate kinase (nm23) in the heart is regulated by $\beta$-adrenergic signaling. $\mathrm{Br} J$ Pharmacol 140: 1019-1026. 
Manning C, Plowman GD, Hunter T, Sudarsanam S (2002) Evolution of protein kinase signalling from yeast to man. Trends Biochem Sci 27: $514-520$.

Manning G, Whyte DB, Martinez R, Hunter T, Sudarsanam S (2002a) The protein kinase complement of the human genome. Science 298: 1912-1934.

Marcus F, Morrison JF (1964) The preparation of phosphoarginine: a comparative study. Biochem J 92: 429-435.

Matthews HR (1995) Protein kinases and phosphatases that act on histidine, lysine, or arginine residues in eukaryotic proteins: a possible regulator of the mitogen activated protein kinase cascade. Pharm Ther 67: 323-350.

Matthews HR, Mackintosh C (1995) Protein histidine phosphatases activity in rat liver and spinach leaves. FEBS Lett 364: 51-54.

Matthews HR, Wei YF (1991) Identification of phosphohistidine in proteins and purification of protein-histidine kinases. Methods Enzymol 200: 388-414.

Mäurer A, Wieland T, Meissl F, Niroomand F, Mehringer R, Krieglstein J, Klumpp S (2005) The $\beta$-subunit of $G$ proteins is a substrate of protein histidine phosphatase. Biochem Biophys Res Commun 334: 1115-1120.

Mc'Tigue JJ, Van Etten RL (1978) An essential active-site histidine residue in human prostatic acid phosphatase. Ethoxyformylation by diethyl pyrocarbonate and phosphorylation by a substrate. Biochim Biophys Acta 523: 407-421.

Meadow ND, Fox DK, Roseman S (1990) The bacterial phosphoenolpyruvate: glycose phosphotransferase system. Annu Rev Biochem 59: $497-542$.

Mehta A, Orchard S (2010) Nucleoside diphosphate kinase (NDPK, NM23, AWD): recent regulatory advances in endocytosis, metastasis, psoriasis, insulin release, fetal erythroid lineage and heart failure; translational medicine exemplified. Mol Cell Biochem 329: 3-15.

Medzihradszky KF, Phillipps NJ, Senderowicz L, Wang P, Turck CW (1997) Synthesis and characterization of histidine-phosphorylated peptides. Protein Sci 6: 1405-1411.

Mizoguchi H, Cook PF, Haseman CA, Uyeda K (1999) Reaction mechanism of fructose 2,6-bisphosphatase. A mutation of nucleophilic catalyst, histidine 256, induces and alteration in the reaction pathway. J Biol Chem 274: 2166-2175.

Muimo R, Banner SJ, Marshal LJ, Mehta A (1998) Nucleotide diphosphate kinase and $\mathrm{Cl}^{-}$sensitive protein phosphorylation in apical membranes form ovine airway epithelium. Am J Respir Cell Mol Biol 18: $270-278$.

Muimo R, Hornickova Z, Riemen CE, Gerke V, Matthews H, Mehta A (2000) Histidine phosphorylation of annexin I in airway epithelia. J Biol Chem 275: 36632-36636.

Mulla A, Christian HC, Solito E, Mendoza N, Morris JF, Buckingham JC (2004) Expression, subcellular localization and phosphorylation status of annexins 1 and 5 in human pituitary adenomas and a growth hormone-secreting carcinoma. Clin Endocrinol (Oxf) 60: $107-119$

Ohmori H, Kuba M, Kumon A (1993) Two phosphatases for 6-phospholysine and 3-phosphohistidine from rat brain. $J$ Biol Chem 268: $7625-7627$.

Ostrowski W (1978) Isolation of tau-phosphohistidine from a phosphoryl-enzyme intermediate of human prostatic acid phosphatase. Biochim Biophys Acta 526: 147-153.

Pigiet V, Conley RR (1978) Isolation and characterization of phosphothioredoxin from Excherichia coli. I Biol Chem 253: 1910-1920.

Pilkis SJ, Walderhaug M, Murray K, Beth A, Venkataramu SD, Pilkis J, El-Maghrabi MR (1983) 6-phosphofructo-2-kinase/fructose 2,6-bisphosphatase from rat liver. J Biol Chem 258: 6135-6141.

Pirrung MC, James KD, Rana VS (2000) Thiophosphorylation of histidine. J Org Chem 65: 8448-8453.

Post RL, Kume S (1973) Evidence for an aspartyl phosphate residue at the active site of sodium and potassium ion transport adenosine triphosphatase. I Biol Chem 248: 6993-7000.

Raynal P, Pollard HB (1994) Annexins: the problem of assessing the biological role for a gene family of multifunctional calcium- and phospholipid-binding proteins. Biochim Biophys Acta 1197: 63-93.

Rescher U, Gerke V (2004) Annexins - unique membrane binding proteins with diverse functions. J Cell Sci 2631-2639.

Robertson EF, Hoyt JC, Reeves HC (1988) Evidence of histidine phosphorylation in isocitrate lyase from Escherichia coli. J Biol Chem 263: $2477-2482$.

Rockman HA, Koch WJ, Lefkowitz RJ (2002) Seven-transmembranespanning receptors and heart function. Nature 415: 206-212.

Rose ZB (1970) Evidence for a phosphohistidine protein intermediate in the phosphoglycerate mutase reaction. Arch Biochem Biophys 140: 508-513.

Ross ARS (2007) Identification of histidine phosphorylations in proteins using mass spectrometry and affinity-based techniques. Methods Enzymol 423: 549-572.

Ross AH, Baltimore D, Eisen HN (1981) Phosphotyrosine-containing proteins isolated by affinity chromatography with antibodies to a synthetic hapten. Nature 294: 654-656.
Rothhut B (1997) Participation of annexins in protein phosphorylation. Cell Mol Life Sci 53: 522-526.

Roymans D, Willems R, Van Blockstaele DR, Slegers H (2002) Nucleoside diphosphate kinase (NDPK/NM23) and the waltz with multiple partners: possible consequences in tumor metastasis. Clin Exp Metastasis 19: 465-476.

Ruman T, Długopolska K, Jurkiewicz A, Kramarz D, Frączyk T, Leś A, Rode W (2009) The synthesis, reactivity and NMR investigation on ${ }^{15} \mathrm{~N}$-thiophosphoramidates. Lett Org Chem 6: 642-647.

Ruman T, Długopolska K, Jurkiewicz A, Rut D, Frączyk T, Cieśla J, Leś A, Szewczuk Z, Rode W (2010) Thiophosphorylation of free amino acids and enzyme protein by thiophosphoramidate ions. Bioorg Chem 38: 74-80.

Samsonoff WA, Reston J, McKee M, O’Connor B, Galivan J, Maley G, Maley F (1997) Intracellular location of thymidylate synthase and its state of phosphorylation. J Biol Chem 272: 13281-13285.

Schenkels C, Erni B, Reymond JL (1999) Phosphofurylalanine, a stable analog of phosphohistidine. Bioorg Med Chem Lett 9: 1443-1446.

Seemann J, Weber K, Gerke V (1997) Annexin I targets S100C to early endosomes. FEBS Lett 413: 185-190.

Shibata K, Inagaki M, Ajiro K (1990) Mitosis-specific histone H3 phosphorylation in vitro in nucleosome structures. Eur J Biochem 192: 87-93.

Smith DL, Bruegger BB, Halpern RM, Smith RA (1973) New histone kinases in nuclei of rat tissues. Nature 246: 103-104.

Smith DL, Chen CC, Bruegger BB, Holtz SL, Halpern RM, Smith RA (1974) Characterization of protein kinases forming acid-labile histone phosphates in Walker-256 carcinoma cell nuclei. Biochemistry 13: 3785-3789.

Smith LS, Kern CW, Halpern RM, Smith RA (1976) Phosphorylation on basic amino acids in myelin basic protein. Biochem Biophys Res Commun 71: 459-465.

Solito E, Christian HC, Festa M, Mulla A, Tierney T, Flower RJ, Buckingham JC (2006) Posttranslational modification plays an essential role in the translocation of annexin A1 from the cytoplasm to the cell surface. FASEB J 20: 1498-500.

Srivastava S, Li Z, Ko K, Choudhury P, Albaqumi M, Johnson AK, Yan Y, Backer JM, Unutmaz D, Coetzee WA, Skolnik EY (2006) Histidine phosphorylation of the potassium channel KCa3.1 by nucleoside diphosphate kinase $\mathrm{B}$ is required for activation of $\mathrm{KCa} 3.1$ and CD4 T cells. Mol Cell 24: 665-675.

Srivastava S, Choudhury P, Li Z, Liu G, Nadkarni V, Ko K, Coetzee WA, Skolnik EY (2006a) Phosphatidylinositol 3-phosphate indirectly activates KCA3.1 via 14 amino acids in the carboxy terminus of KCa3.1. Mol Biol Cell 17: 146-154.

Srivastava S, Zhdanova O, Di L, Li Z, Albaqumi M, Wulff H, Skolnik EY (2008) Protein histidine phosphatases 1 negatively regulates CD4 $\mathrm{T}$ cells by inhibiting the $\mathrm{K}^{+}$channel KCa3.1. Proc Natl Acad Sci USA 105: 14442-14446.

Stadtman TC (1994) Emerging awarness of the critical roles of S-phosphocysteine and selenophosphate in biological systems. BioFactors 4: 181-185.

Steeg PS, Palmieri D, Ouatas T, Salerno M (2003) Histidine kinases and histidine phosphorylated proteins in mammalian cell biology, signal transduction and cancer. Can Lett 190: 1-12.

Steiner AW, Helander ER, Fujitaki JM, Smith LS, Smith RA (1980) High-performance liquid chromatography of acid-stable and acidlabile phosphoamino acids. J Chromatogr 202: 263-269.

Stock JB, Stock AM, Mottonen JM (1990) Signal transduction in bacteria. Nature 344: 395-400.

Stock AM, Robinson VL, Goudreau PN (2000) Two-component signal transduction. Annu Rev Biochem 69: 183-215.

Tan E, Besant PG, Attwood PV (2002) Mammalian histidine kinases: do they really exist? Biochemistry 41: 3843-3851.

Tan E, Lin SG, Zu X, Yeoh GC, Besant PG, Attwood PV (2003) Detection of histidine kinases via a filter-based assay and reverse-phase thin-layer chromatographic phosphoamino acid analysis. Anal Biochem 323: 1222-1226.

Tan E, Besant PG, Zu XL, Turck CW, Bogoyevitch MA, Lin SG, Attwood PV, Yeoh GC (2004) Histone H4 histidine kinase displays the expression pattern of a liver oncodevelopmental marker. Carcinogenesis 25: 2083-2088.

Treharne KJ, Crawford RM, Mehta A (2006) CFTR, chloride concentration and cell volume: could mammalian protein histidine phosphorylation play a latent role? Exp Physiol 91: 131-139.

Wakim BT, Aswad GD (1994) $\mathrm{Ca}^{2+}$-calmodulin-dependent phosphorylation of arginine in histone 3 by a nuclear kinases from mouse leukemia cells. J Biol Chem 269: 2722-2727.

Wakim BT, Grutkoski PS, Vaughan AT, Engelmann GL (1995) Stimulation of a $\mathrm{Ca}^{2+}$-calmodulin-activated histone 3 arginine kinase in quiescent rat heart endothelial cells compared to actively dividing cells. J Biol Chem 270: 23155-23158.

Waygood EB, Erickson E, el-Kabbani OA, Delbaere LT (1985) Characterization of phosphorylated histidine-containing protein $(\mathrm{HPr})$ of the bacterial phosphoenolpyruvate:sugar phosphotransferase system. Biochemistry 24: 6938-6945. 
Wålinder O (1968) Identification of a phosphate-incorporating protein from bovine liver as nucleoside diphosphate kinase and isolation of 1-32P-phosphohistidine, 3-32P-phosphohistidine, and N-epsilon32P-phospholysine from erythrocytic nucleoside diphosphate kinase, incubated with adenosine triphosphate-32P. J Biol Chem 243: 3947-3952.

Wei YF, Matthews HR (1990) A filter-based protein kinase assay selective for alkali-stable protein phosphorylation and suitable for acidlabile protein phosphorylation. Anal Biochem 190: 188-192.

Wettschureck N, Offermanns S (2005) Mammalian G proteins and their cell type specific functions. Physiol Rev 85: 1159-1204.

Wieland T (2007) Interaction of nucleoside diphosphate kinase B with heterotrimeric $G$ protein $\beta \gamma$ dimers: consequences on $G$ protein activation and stability. Naunyn-Schmiedeberg's Arch Pharmacol 374: 373-383.

Wieland T, Ulibarri I, Gierschik P, Jakobs KH (1991) Activation of signal-transducing guanine-nucleotide-binding regulatory proteins by guanosine 5'-[ $\gamma$-thio]triphosphate. Information transfer by intermediately thiophosphorylated $\beta \gamma$ subunits. Eur J Biochem 196: 707-716.

Wieland T, Ronzani M, Jakobs KH (1992) Stimulation and inhibition of human platelet adenylcyclase by thiophosphorylated transducin By-subunits. J Biol Chem 267: 20791-20797.

Wieland T, Nürnberg B, Ulibarri I, Kaldenberg-Stasch S, Schultz G, Jakobs KH (1993) Guanine nucleotide-specific phosphate transfer by guanine nucleotide-binding regulatory protein $\beta$-subunits. Characterization of the phosphorylated amino acid. J Biol Chem 268: 18111-18118.

Wieland T, Hippe H-J, Ludwig K, Zhou X-B, Korth M, Klumpp S (2010) Reversible histidine phosphorylation in mammalian cells: a teeter-totter formed by nucleoside diphosphate kinase and protein histidine phosphatase 1. Methods Ensymol 471: 379-402.

Williams SP, Sykes BD, Bridger WA (1985) Phosphorus-31 nuclear magnetic resonance study of the active site phosphohistidine and regulatory phosphoserine residues of rat liver ATP-citrate lyase. Biochemistry 24: 5527-5531.

Wilson ME, Consigli RA (1985) Characterization of a protein kinase activity associated with purified capsids of the granulosis virus infecting Plodia interpunctella. Virology 143: 516-525.

Wong C, Faiola B, Wu W, Kennelly PJ (1993) Phosphohistidine and phospholysine phosphatases activities in the rat: potential proteinlysine and protein-histidine phosphatases? Biochem J 296: 293-296.

Yano M, Mori S, Kido H (1999) Intrinsic nucleoside diphosphate kinase-like activity is a novel function of $20 \mathrm{~S}$ proteasome. $J$ Biol Chem 274: 34376-34382.

Zetterquist Ö, Engström L (1967) Isolation of N-e-[32P]phosphoryllysine from rat-liver cell sap after incubation with [32P] adenosine triphosphate. Biochim Biophys Acta 141: 523-532.

Zoroddu M, Kowalik-Jankowska T, Kozłowski H, Molinari H, Salnikow K, Broday L, Costa M (2000) Interaction of $\mathrm{Ni}(\mathrm{II})$ and $\mathrm{Cu}(\mathrm{II})$ with a metal binding sequence of histone H4: AKRHRK, a model of the H4 tail. Biochem Biophys Acta 1475: 163-168.

Zu XL, Besant PG, Imhof A, Attwood PV (2007) Mass spectrometric analysis of protein histidine phosphorylation. Amino Acids 32: 347-357.

Zu XL, Besant PG, Attwood PV (2009) Protein histidine phosphorylation. Comprehensive Analytical Chemistry 52: 315-352. 